\title{
LABOR LAW: FIFTH GIRCUIT DETERMINES THAT BREACH OF DUTY OF FAIR REPRESENTATION CONSTITUTES AN UNFAIR LABOR PRACTICE
}

In the first case in which the issue was the subject of an appeal, the Fifth Circuit held that a labor union's breach of its duty of fair representation by racially discriminating among its members constituted an unfair labor practice under the National Labor Relations $A c t$, and was therefore remediable by the NLRB. The court also focused on the jurisdictional relationship between the Civil Rights Act of 1964 and the National Labor Relations Act, implying that the Act's Equal Employment Opportunity Commission did not have exclusive jurisdiction over unfair representation claims based on racial-discrimination. The court's resolution of these issues, however, points to the need for further congressional action in this area.

$A_{\text {bargaining representative's duty of fair representation has been }}$ firmly established under the National Labor Relations Act (NLRA). Until recently, however, the manner in which this duty is to be enforced has not been delineated by the courts. Further, whether a breach of the duty constitutes an unfair labor practice has similarly remained unresolved. Raising both these matters, in Local 12, United Rubber Workers v. NLRB, ${ }^{1}$ the Fifth Circuit Court of Appeals held that such a breach does constitute an unfair labor practice under section $8(\mathrm{~b})(\mathrm{I})(\mathrm{A})$ of the $\mathrm{NLRA}^{2}$ and that, therefore, unfair representation is remediable by the NLRB. ${ }^{3}$ In positing its solution to the jurisdictional problems of enforcing fair representation, the United Rubber Workers court became the first federal tribunal to focus on the relationship of the Civil Rights Act of $1964^{4}$ to the NLRA and on the Act's potential conflicts with NLRB powers.

The collective bargaining contract considered in United Rubber Workers provided for plant-wide seniority without regard to race.

1368 F.2d 12 (5th Cir. 1966), cert. denied, 36 U.S.L.W. 3144 (U.S. Oct. 10, 1967) (No. 194).

Labor-Management Relations Act (Taft-Hartley Act) $\$ 8(\mathrm{~b})(1)(\mathrm{A}), 29$ U.S.C. $\S 158$ (b) (I) (A) (1964) [hereinafter cited as LMRA]. The LMRA amended and added to the NLRA.

a See National Labor Relations Act (Wagner Act) \$10, 29 U.S.C. $\$ 160$ (1964) [hereinafter cited as NIRA].

¿ Civil Rights Act of 1964, $\S 7116$ (a)-(b), 42 U.S.C. $\$ 2000$ e (1964). 
However, Local 12 had maintained a policy of racially separate seniority lists for nearly twenty years; and during 1960-61 the employer, Goodyear Tire and Rubber Company of East Gadsden, Alabama, laid off eight Negro employees while retaining less senior white employees. The eight filed affidavits with the union grievance committee alleging that their layoff had not been in accordance with the seniority provisions. Although the committee refused to process the grievances, the Negroes were reinstated when the president of the international union interceded at their request. Since Local 12 continued to refuse to process the Negroes' grievances concerning segregated plant facilities and back wages for the layoff period, the Negroes filed a charge with the NLRB. ${ }^{5}$ Contrary to the decision of the Trial Examiner, the NLRB found that the employees' right to fair representation had been violated by the union's refusal to act. ${ }^{6}$ The Board concluded that fair representation is an indispensable element of the LMRA section 7 rights which are protected by section $8(b)(1)(A)^{z}$ and that such a violation is remediable as

${ }^{8}$ Since the grievance for backpay was derived from an alleged breach of the collective bargaining contract, the eight Negroes probably could have brought suit under $\S 301$ of the LMRA. Smith v. Evening News Ass'n, 371 U.S. 195 (1962); LMRA §301 (a), 29 U.S.C. $\$ 185$ (1964). Section 301 (a) states: "Suits for violation of contracts between an employer and a labor organization representing employees ... may be brought in any district court of the United States having jurisdiction of the parties . . . ." Suit could not be brought under $\S 301$ for the desegregation of plant facilities, since the collective bargaining agreement did not deal with this subject. See 368 F.2d at 14 . On the other hand, the contract would support a $\$ 301$ suit if failure to process a grievance concerning segregated facilities is deemed a prima facie violation of the collective bargaining contract. For an analysis of the failure to process the grievance as an unfair labor practice see notes $49-52$ infra and accompanying text. Unfair representation has been held to be a $\$ 301$ violation. See Humphrey v. Moore, 375 U.S. 335 (1964). Contra, 375 U.S. at 351 (concurring opinion of Goldberg, J.). See generally Rosen, Fair Representation, Contract Breach and Fiduciary Obligations: Unions, Union Officials and the Worker in Collective Bargaining, 15 HAsrincs L.J. 391, 409-19 (1964); Comment, Refusal to Process a Grievance, the NLRB, and the Duty of Fair Representation: A Plea for Pre-emption, 26 U. PITT. L. REv. 593, 594-96, 610-19 (1965).

- Local 12, United Rubber Workers, 150 N.L.R.B. 3J2, 315-19 (1964).

IId. at $\$ 19-20$. See LMRA \& 8 (b) (I) (A). 29 U.S.C. $\$ 158$ (b) (1) (A) (J964). Section 8 (b) (1) (A) provides that it is an unfair labor practice for a union to "restrain or coerce" employees in the exercise of their $\$ 7$ rights. Section 7 provides: "Employees shall have the right to self-organization, to form, join, or assist labor organizations, to bargain collectively through representatives of their own choosing, and to engage in other con. certed activities for the purpose of collective bargaining or other mutual aid or protection, and shall also have the right to refrain from any and all such activities ....." LMRA \$7, 29 U.S.C. $\$ 157$ (1964) (emphasis added).

The United Rubber Workers court did not address itself to the problem of what constitutes "restraint or coercion," evidently assuming that unfair representation is coercion under $\S 8$ (b) (1) (A). See 368 F.2d at 17. Nevertheless, $\$ 8$ (b) (1) (A) arguably promulgates a less stringent restriction on unions than does $\$ 8$ (a) (1) on employers; 
an unfair labor practice under section $8(b)(1)(A)$. Subsequently, the Fifth Gircuit affirmed. ${ }^{8}$

When a union enjoying the status of exclusive representative of all employees in a bargaining unit refuses to act on behalf of those it represents or takes hostile action against any segment of those employees for irrelevant or invidious reasons, it violates its duty of fair representation. ${ }^{8}$ Racial discrimination was the genesis of the fair representation doctrine, ${ }^{10}$ but the duty has been extended to include any invidious discrimination not related to legitimate labor union objectives. ${ }^{11}$ All discrimination among union members, however, is not prohibited since the union is allowed a wide range of discretion in internal policies. ${ }^{12}$ While the duty applies to both

the former prohibits only union activity which "restrains" or "coerces" employees, whereas $\$ 8$ (a) (1) prohibits employer activity which merely "interferes" with the exercise of $\S 7$ rights. See NLRB v. Drivers Local 639, 362 U.S. 274, 285-86 (1960). Compare $\S 8$ (a) (1), 29 U.S.C. $\S 158$ (a) (1) (1964), with $\S 8$ (b) (1)(A), 29 U.S.C. $\S 158$ (b) (1) (A) (1964). However, in pre-Taft-Hartley interpretation, employer interference which did not also restrain and coerce had never been held illegal, and the Conference Committee's elimination of the word "interference" in $\$ 8(\mathrm{~b})(1)$ (A) codified this interpretation of $\S 8$ (a) (1). H.R. REP. No. 510, 80th Cong., 1st Sess. 43 (1947). See also International Ladies' Garment Workers' Union v. NLRB, 366 U.S. 731, 738 (1961); notes 35-42 infra and accompanying text.

8 368 F.2d at 12. The NLRB had also found violations of $\$ 8$ (b) (2) (caused or attempted to cause the employer to discriminate against complainants) and $\$ 8$ (b) (3) (refused to bargain in compainant's behalf). LMRA $\$ \$ 8(\mathrm{~b})$ (2), (3), 29 U.S.C. $\S \S 158$ (b) (2), (3) (1964); Local 12, United Rubber Workers, 150 N.L.R.B. 312, 317 n.5, $319-20$ (1964). However, the Fifth Circuit did not reach the $\$ \$ 8(\mathrm{~b})(2)$ or (3) issues since the NLRB's order was enforceable on the basis of the $\$ 8$ (b) (1) (A) violation.

- Steele v. Louisville \& N.R.R., 323 U.S. 192, 202-03 (1944); see Wallace Corp. v. NLRB, 323 U.S. 248, 255 (1944). See generally Aaron, Some Aspects of the Union's Duty of Fair Representation, 22 Oнго ST. L.J. 39 (1961); Blumrosen, The Worker and Three Phases of Unionism: Administrative and Judicial Control of the WorkerUnion Relationship, 61 Mich. L. REv. 1435, 1469-72 (1963); Cox, The Duty of Fair Representation, 2 VILL. L. REv. 151 (1957).

For the possibility of a Shelley v. Kramer, 334 U.S. 1 (1948) (state judicial enforcement of discriminatory covenants prohibited by Fourteenth Amendment), consideration in the area of unfair representation, see Comment, 65 CoLUM. L. REV. 273, 285-87 (1965).

${ }^{10}$ See, e.g., Brotherhood of R.R. Trainmen v. Howard, 343 U.S. 768 (1952) (unfair representation for union to use discriminatory bargaining device to oust Negro train porters and replace them with white brakemen); Stecle v. Louisville \& N.R.R., 323 U.S. 192 (1944) (unfair representation to discriminate against Negro firemen in favor of white firemen).

${ }^{11}$ Hargrove v. Brotherhood of Locomotive Eng'rs, 116 F. Supp. 3 (D.D.C. 1953); Ford Motor Co. v. Huffman, 345 U.S. 330 (1953) (dictum); cf. Humphrey v. Moore, 375 U.S. 335 (1964); Wallace Corp. v. NLRB, 323 U.S. 248 (1944).

${ }^{12}$ In Ford Motor Co. v. Huffman, 345 U.S. 330 (1953), the Supreme Court emphasized the fact that the duty of fair representation does not preclude all distinctions among the members of unions: "The complete satisfaction of all who are represented is hardly to be expected. A wide range of reasonableness must be allowed a statutory 
the negotiation and administration of a collective bargaining agreement, ${ }^{13}$ the union may be allowed somewhat more discretion in negotiating the agreement. ${ }^{14}$

The duty of fair representation was first articulated in Steele $v$. Louisville \& Nashville R.R., ${ }^{15}$ wherein the Supreme Court found that concomitant to exclusive representative status under the Railway Labor Act there was an implicit duty to represent all members of the bargaining unit fairly. ${ }^{16}$ As a standard for future determinations, the Court decreed that union members must be represented "without hostile discrimination, fairly, impartially, and in good faith."17 Relying on the reasoning of Steele, the Court, in Wallace Corporation $v . N L R B,{ }^{18}$ implied that section 9 of the NLRA similarly imposes an obligation of fair representation upon the industrial bargaining representative. Initially, the only remedy for breach of the duty was judicial enforcement. ${ }^{10}$ Steele had reasoned that

bargaining representative in serving the unit it represents, subject always to complete good faith and honesty of purpose in the exercise of its discretion." Id. at 338; see Steele v. Louisville \& N.R.R., 323 U.S. 192 (1944)

${ }^{13}$ Conley v. Gibson, 355 U.S. 41, 46 (1957): "The bargaining representative's duty [of fair representation] ... does not come to an abrupt end ... with the making of an agreement between union and employer. Collective bargaining is a continuing process. Among other things, it involves day-to-day adjustments in the contract and other working rules, resolution of new problems not covered by existing agreements, and the protection of employee rights already secured by contract. The bargaining representative can no more unfairly discriminate in carrying out these functions than it can in negotiating a collective agreement."

14 See Elgin, J. \& E. Ry. v. Burley, 325 U.S. 711, 739-41 (1945).

16323 U.S. 192 (1944).

${ }^{10}$ The Supreme Court recognized that valid differences might exist in the terms of a contract, but declared that discriminations based on race alone "are obviously irrelevant and invidious." Id. at 203. Following Steele, judicial relief was granted in a number of cases for unfair representation under the Railway Labor Act. E.g., Conley v. Gibson, 355 U.S. 41 (1957); Brotherhood of R.R. Trainmen v. Howard, 343 U.S. 768 (1952).

17323 U.S. at 204.

${ }^{28} 323$ U.S. 248 (1944). The Supreme Court stated that by selection of the union as the bargaining representative under $\$ 9$ of the NLRA, the union became the agent of all the employees and was implicitly charged with the "responsibility of representing their interests fairly and impartially." Id. at 255. The duty of fair representation was more explicitly extended to the NLRA by Syres v. Oil Workers Union, 350 U.S. 892, rev'g 223 F.2d 739 (5th Cir. 1955); Ford Motor Co. v. Huffman, 345 U.S. 330 (1953) (dictum). See also NLRA §9 (a), 29 U.S.C. \$159 (a) (1964).

${ }_{10}$ Since the legal status of unions was derived largely from federal legislation, governmental authority might have been expected to insure a fair exercise of power over union members. However, at its inception, national labor policy showed a high degree of solicitude for employees rights which were largely to the detriment of labor organizations, but did not concern itself with employee rights within a union or through a union. See Hitchman Coal \& Coke Co. v. Mitchell, 245 U.S. 229, 250.51 (1917) (upheld "yellow dog" contracts); Vegelahn v. Guntner, 167 Mass. 92, 44 N.E. 
a judicial resolution was mandatory since there were no provisions for administrative remedies under the Railway Labor Act. ${ }^{20}$ Wallace, which preceded the adoption of unfair labor practice remedies by the NLRA, accepted the Steele remedial limitations. ${ }^{21}$ Since the NLRB did not attempt to enforce the obligation of fair representation as an unfair labor practice until 1962, unfair representation claims subsequent to Wallace and prior to 1962 were generally redressed in the courts. ${ }^{22}$

The NLRB, however, did employ sanctions against illegally dis-

1077 (1896) (picketing that interferes with employees who are not picketing is unlawful). After the passage of the Railway Labor Act and the NLRA, the policy shifted to a preoccupation with the formation of unions and the operation of collective bargaining as a basis of labor-management relations. See LMRA § 1, 29 U.S.C. § 141 (1964); NLRA § 1, 29 U.S.C. § 151 (1964); The Railway Labor Act \$2, 45 U.S.C. \$152 (1964). Implicit in this shift was the assumption that employee interests were synonomous with those of the union representing them. See A. Cox \& D. BoK, LABor LAw 915 (1965). Therefore, at first the only real safeguards against unfair representation came in the form of state remedies such as sanctioning arbitrary disciplining of union members, e.g., Rueb v. Rehder, 24 N.M. 534, 174 P. 992 (1918); Polin v. Kaplan, 257 N.Y. 277, 177 N.E. 833 (1931), ordering an accounting of funds, see, e.g., Dusing v. Nuzzo, 177 Misc. 35, 29 N.Y.S.2d 882 (Sup. Ct.), modified, 263 App. Div. 59, 31 N.Y.S.2d 849 (1941); Collins v. International Alliance of Theatrical Stage Employees, 119 N.J. Eq. 230, 244-45, 182 A. 37, 45 (Ct. Ch. 1935). See also Duke v. Franklin, 177 Ore. 297, 302-04, 162 P.2d 141, 143-44 (1945); Wilson v. Miller, 194 Tenn. 390, 250 S.W.2d 575 (1952), and requiring and supervising union elections of officers, see, e.g., Wilson v. Miller, supra; Sibilia v. Western Elec. Employees Ass'n, 142 N.J. Eq. 77, 59 A.2d 251 (Ct. Err. \& App. 1948); O'Neill v. United Ass'n of Journeymen Plumbers, $348 \mathrm{~Pa}$. 531, 36 A.2d 325 (1944); Raevsky v. Upholsterers' Int'l Union, $38 \mathrm{~Pa}$. D. \& C. 187 (Phila. C.P. 1940). See generally Cox, The Role of Law in Preserving Union Democracy, 72 HARv. L. REv. 609, 624-27 (1959); Summers, Judicial Regulation of Union Elections, 70 YALE L.J. 1221 (1961). The usual underlying legal theory of state judicial action is that the union constitution is a contract between the union and its members and thus is enforceable in the courts. See, e.g., Polin v. Kaplan, supra at 281-82, 177 N.E. at 834. See generally Summers, The Law of Union Discipline: What the Courts Do in Fact, 70 YALE L.J. 175 (1960).

${ }_{20} 323$ U.S. at 207; see Graham v. Brotherhood of Locomotive Firemen, 338 U.S. 232, 239 (1949); Tunstall v. Brotherhood of Locomotive Firemen, 322 U.S. 210, 213 (1944).

${ }_{21}$ See 323 U.S. at 255. Unfair labor practice prohibitions and remedies were not enacted until 1947, while Wallace was decided in 1943.

${ }^{22}$ See, e.g., Republic Corp. v. Maddox, 379 U.S. 650, 652 (1965); Humphrey v. Moore, 375 U.S. 335, 344 (1964); Local 100, United Ass'n of Journeymen v. Borden, 373 U.S. 690, 696 n.7 (1963); Syres v. Oil Workers Int'l Union, 350 U.S. 892, rev'g 223 F.2d 739 (5th Cir. 1955); Ford Motor Co. v. Huffman, 345 U.S. 330 (1953). The NLRB apparently felt initially that it did not have the power to enforce fair representation under $\$ 8$ (b) (1) (A). See Case No. K-311, 37 L.R.R.M. 1457 (1956); Case No. 1047, 35 L.R.R.M. 1130 (1954). In an Amicus Curiae Brief to the Supreme Court, the NLRB stated: "[L]egislative history . . does not indicate that Congress contemplated that the right of employees to receive fair and equal treatment from their bargaining representative would be brought within the scope of that protection." Brief for NLRB as Amicus Curiae at 15-16, Ford Motor Co. v. Huffman, 345 U.S. 330 (1953). 
criminatory representation before 1962 through refusing to aid offending unions to become or remain exclusive bargaining representatives under section 9 by revoking certification and abrogating the contract bar rules. ${ }^{23}$ However, these measures were ineffective against strong unions to which certification has little practical significance. ${ }^{24}$ Further, since the individual employee was afforded no direct relief, ${ }^{25}$ these sanctions had little practical effect and were seldom employed. ${ }^{28}$

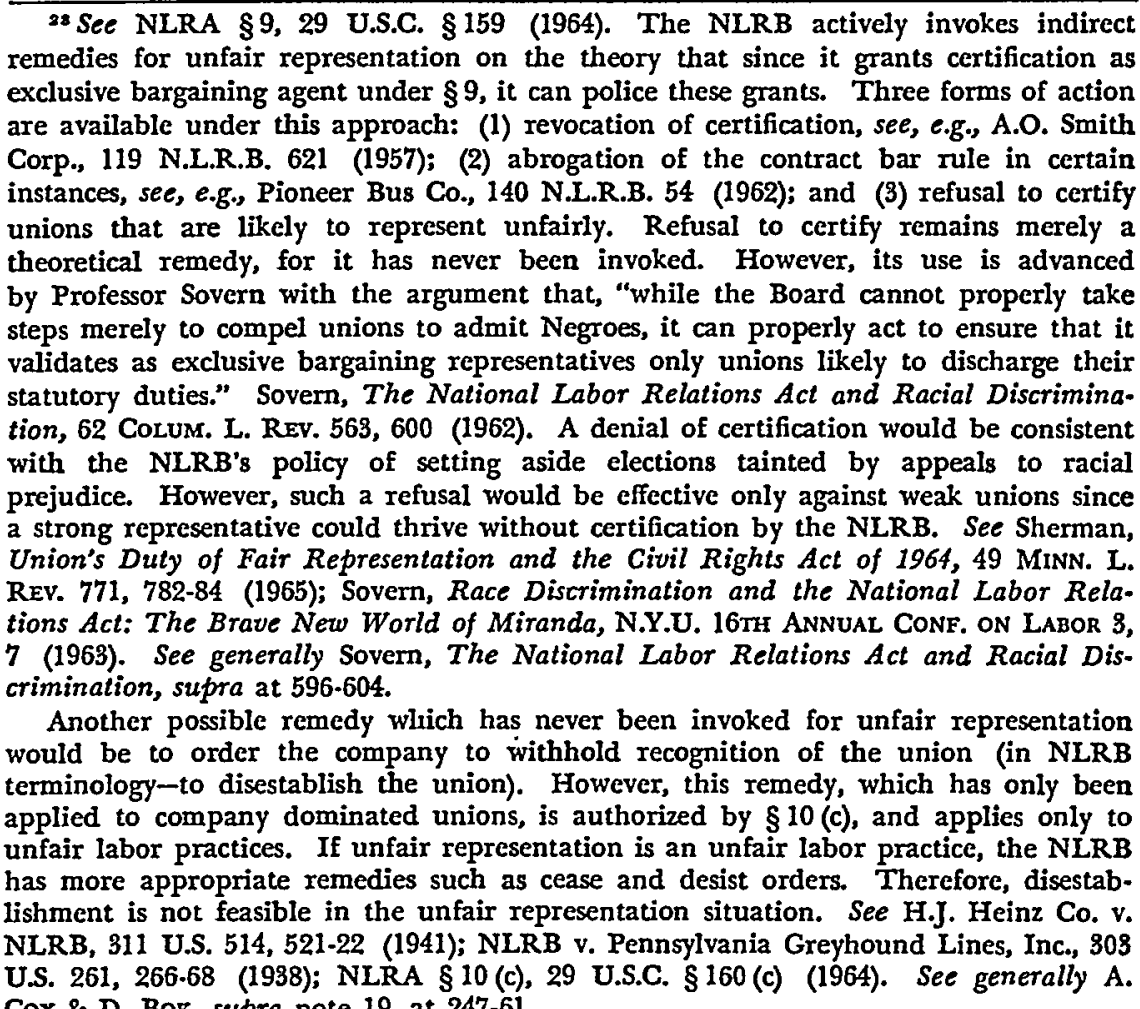
Cox \& D. Bok, supra note 19 , at 247-61.

24 See Albert, NLRB-FEPC7, 16 VAND. L. REv. 547, 558-59 (1963); Cox, The Duty of Fair Representation, 2 ViLL. L. REv. 151, 175 (1957); Note, 112 U. PA. L. REV. 711,714 (1964).

s5 See Note, 112 U. PA. L. REv. 711, 714 (1964).

${ }^{30}$ Decertification or the threat of it has been used to promote fair representation in several instances. See, e.g., A.O. Smith Corp., 119 N.L.R.B. 621 (1957) (revoked because union failed to represent 18 workers); Pittsburgh Plate Glass Co., 111 N.I.R.B. 1210 (1955) (threatened decertification); Larus \& Brother Co., 62 N.L.R.B. 1075 (1945) (same); Carter Mfg. Co., 59 N.L.R.B. 804 (1944) (same). See generally Albert, supra note 24, at 558-63. Abrogation of the contract bar rule has also been used to en. courage fair representation in a few instances. See, e.g., Pioneer Bus Co., 140 N.L.R.B. 54 (1962) (held contract with certified union was no bar to new election because of 
The NLRB first asserted jurisdiction over unfair representation as an unfair labor practice within the ambit of section 8 (b) (1) (A) in Miranda Fuel Company. ${ }^{27}$ A truck driver for Miranda was reduced in seniority by the union because he had left work on a leave of absence three days earlier than provided for in the contract. He complained to the NLRB that the union was acting arbitrarily in derogation of his interests. A majority of the Board held that the reduction of seniority violated sections 8 (b) (1) (A) and 8 (b) (2). ${ }^{28}$ On appeal, the Second Circuit denied enforcement of the NLRB's order, but without an express majority rejection of the Board's section 8 (b)(1) (A) theory. ${ }^{29}$ Two judges did not pass upon the Board's theory; ${ }^{30}$ and a third, Judge Medina, rejected it on the ground that unfair representation not related to union membership cannot support a finding of an 8 (b) (1) (A) violation..$^{31}$ He reasoned that since sections 8 (b) (2), 8 (b) (3), 8 (a)(3), and 8 (a) (5) were intended to affect only union considerations, Congress must have intended that the application of section 8 (b) (1) (A) be limited to conduct affecting membership in a union. ${ }^{32}$ While the NLRB has nevertheless extended its

discriminatory conduct); Pittsburgh Plate Glass Co., supra (certification revoked and contract held no bar to new election); cf. Sewell Mfg. Co., 138 N.L.R.B. 66 (1962). See generally Albert, supra note 24 , at 563-81.

${ }_{27} 140$ N.L.R.B. 181 (1962), modified, 326 F.2d 172 (2d Cir. 1963).

${ }^{28}$ LMRA $\$ \$ 8$ (b) (1) (A), 8 (b) (2), 29 U.S.C. $\$ \$ 158$ (b) (1) (A), (b) (2) (1964). Section 8 (b) (2) provides that it is an unfair labor practice "to cause or attempt to cause an employer to discriminate against an employee in violation of" $\$ 8$ (a) (3), which prohibits "... discrimination in regard to hire or tenure of employment or any term or condition of employment to encourage or discourage membership in any labor organzia. tion ....."

${ }^{20}$ NLRB v. Miranda Fuel Co., 326 F.2d 172 (2d Cir. 1963).

${ }^{30}$ Chief Judge Lumbard concurred with Judge Medina, but upon the belief that the evidence did not show unfair representation and, therefore, it was unnecessary to pass upon the NLRB's $\$ 8$ (b) (1) (A) theory. 326 F.2d at 180 . Judge Friendly declined to pass on $\S 8(\mathrm{~b})(1)(\mathrm{A})$, as he felt the union had violated $\S 8(\mathrm{~b})(2)$. Id. at $180-81$ \& n.1.

s1 Id. at 175 .

s2 Id. at 175-76. Judge Medina reasoned that since $\$ 8(\mathrm{~b})(3)$ is merely the counterpart of the employer's duty to bargain collectively under $\$ 8$ (a) (5), and since $\S 8$ (b) (2) and $\$ 8(\mathrm{~b})(3)$ require a showing of discrimination that encouraged or discouraged union membership, to constitute an unfair labor practice under $\S 8$ "the union or the employer must have committed some act the natural and foreseeable consequence of which is to be beneficial or detrimental to the union." Id. at 176. His reasoning closely paralleled that of the dissenters in the NLRB opinion: "Even assuming arguendo that the Section 9 duty of fair representation can be read into Section 7, it does not follow that the prohibitory provisions of Section 8 (a) (1) or 8 (b) (1) (A), or even all the provisions of Section 8, provide a remedy for all the incursions upon those rights, or make the Board the exclusive guardian of those rights." 140 N.L.R.B. at 200. 
8 (b) (1)(A) theory to other unfair representation cases, ${ }^{33}$ United Rubber Workers is the first case in which the theory has been the subject of an appeal. ${ }^{34}$

In United Rubber Workers, the Fifth Circuit upheld the NLRB's position that the duty of fair representation comprises an "indispensable element of the right of employees 'to bargain collectively through representatives of their own choosing,' " as guaranteed in section $7 .^{85}$ Since section 8 (b) (1) (A) makes it an unfair labor practice to restrain or coerce employees in the exercise of their section 7 rights, the union violated that section when it failed to fairly represent the employees. ${ }^{36}$ Rejecting Judge Medina's position in Miranda, ${ }^{37}$ the Fifth Circuit decided that section $8(\mathrm{~b})(\mathrm{l})(\mathrm{A})$ is not restricted to discrimination that encourages or discourages union membership: ${ }^{88}$ the other section 8 provisions, though limited to

On the other hand, most courts have construed $\$ 8(\mathrm{~b})(1)(A)$ to encompass a wide range of conduct. E.g., International Ladies' Garment Workers' Union v. NLRB, 366 U.S. 731 (1961) (union accepted exclusive bargaining authority when only a minority of employees had authorized the union to represent their interests); Communications Workers v. NLRB, 362 U.S. 479 (1960) (union coerced employees in the exercise of their right to refrain from or discontinue participation in a strike); Radio Officers' Union v. NLRB, 847 U.S. 17 (1954) (employee coerced in his statutory right to refrain from observance of union rules); NLRB v. United Packinghouse Workers, 274 F.2d 816 (5th Cir. 1960) (unlawful violent conduct during strike); NLRB v. International Woodworkers, 243 F.2d 745 (5th Cir. 1957) (threats of violence during strike). However, some courts have defined limits for the section by ruling that there is no "restraint or coercion" under specific circumstances. E.g., NLRB v. News Syndicate Co., 365 U.S. 695 (1961) (hiring only union men is not illegal per se); Local 357, International Bhd. of Teamsters v. NLRB, 365 U.S. 667 (1961) (hiring hall arrangement is not illegal per se); NLRB v. Local 639, Teamsters, 362 U.S. 274 (1960) (peaceful picketing of minority union for recognition is not conduct that "coerces" employees in the exercise of their $\$ 7$ rights).

as See Local 12, United Rubber Workers, 150 N.L.R.B. 312 (1964); Local 1367, Longshoremen, 148 N.L.R.B. 897 (1964), aff'd, 368 F.2d 1010 (5th Cir. 1966), cert. denied, 36 U.S.L.W. 3144 (U.S. Oct. 10, 1967) (No. 212). In the latter case, the NLRB found a $\$ 8(\mathrm{~b})(\mathrm{l})$ (A) violation because a union maintained a $75.25 \%$ work distribution between two racially segregated locals and enforced a "no doubling" arrangement forbidding the assignment of white and Negro gangs to work together in ship hatches. In Hughes Tool Co., 147 N.L.R.B. 1573, 1575 (1964), the issue was whether a jointly certified union had breached its duty of fair representation when it refused to process the grievance of a Negro member of the bargaining unit who also was a member of the other jointly certified union. Applying the Miranda theory, the majority of the NLRB found violations of $\S 8$ (b) (1) (A) and $\S 8(\mathrm{~b})$ (2). See International Union, UAW, 149 N.L.R.B. 482 (1964).

34 368 F.2d 12 (5th Cir. 1966), cert. denied, 36 U.S.L.W. 8144 (U.S. Oct. 10, 1967) (No. 194).

${ }^{8} I d$. See note 7 supra.

30 368 F.2d at 17 .

87 See notes 31-32 supra and accompanying text.

8368 F.2d at 20. 
union considerations, should not be allowed to limit the section 7 rights enforced by section 8 (b) (1) (A). ${ }^{39}$

Some commentators have argued that the absence of any specific legislative authorization, coupled with the rejection of specific proposals to include the duty, ${ }^{40}$ is indicative of an intent not to impose this representational obligation. ${ }^{41}$ Conversely, other commentators reason that since Congress enacted unfair labor practices after the Supreme Court had ruled in Wallace that the duty of fair representation is implicit in the NLRA, Congress impliedly adopted an unfair labor practice remedy for unfair representation. ${ }^{42}$ Nevertheless, the

so Id.

'0 See Note, 63 Mrcr. L. REv. 1081, 1085 (1965); Note, Administrative Enforcement of the Right to Fair Representation: the Miranda Case, 112 U. PA. L. REv. 711, 719-21 (1964). The LMRA added $\S 8$ (b) (1) (A) to the NLRA and amended $\S 7$ to include as a protected right the refraining from participation in any activity covered by $\$ 7$. It has been hypothesized that the amending sequence indicates that the proscription of $\S 8$ (b) (1) (A) was apparently a counterpart to the original $\S 8$ (a) (1) of the NLRA, which imposed the same restrictive limitation on employers. Since $\$ 8$ (a) (1) does not contain a duty of fair representation for employers, the correlative theory would compel the conclusion that there is no duty of fair representation in $\$ 8$ (b) (l) (A). See Note, 63 Mich. L. REv. 1081, 1085 (1965); Note, 112 U. PA. L. REv., supra at 719-20.

NLRB jurisdiction over unfair representation charges has been opposed on the basis that it would conflict with policies concerning jurisdiction, see notes 74-85 infra and accompanying text; the Civil Rights Act of 1964, see notes 60-74 infra and accompanying text; and the LMRA, see Note, 112 U. PA. L. REv., supra at 722-23.

"1 See, e.g., Sherman, supra note 22, at 792; Sovern, Race Discrimination and the National Labor Relations Act: The Brave New World of Miranda, N.Y.U. 16rH ANNuAL CONF. ON LABOR 3, 13 (1963). See generally Note, Administrative Enforcement of the Right to Fair Representation: the Miranda Case, 112 U. PA. L. REv. 711 (1964). But see Blumrosen, supra note 9, at 1509-11; Comment, A Union's Duty of Fair Representation: Historical Support for Administrative Enforcement, 2 Housr. L. REv. 373, 381.86 (1965).

${ }^{42} \mathrm{~A}$ corollary to the argument that unfair representation is an unfair labor practice is the contention that if Congress had meant to exclude the duty of fair representation from $\$ 8(\mathrm{~b})(\mathrm{l})(\mathrm{A})$, it should have explicitly stated that fair representation was not a part of $\$ 7$. Professor Sovern maintains that an actual "vehicle" for the expression of any such intent by Congress existed. In referring to a clause in $\$ 7$ of the NLRA which reads: "Provided, that this paragraph shall not impair the right of a labor organization to prescribe its own rules with respect to the acquisition or retention of membership therein," he stated, "only the words 'or to represent unfairly' needed to be added to assure a contrary result in Miranda. This does not, of course, establish a legislative intent in support of Miranda. The point is only that Congress' intent is unclear or, more realistically, nonexistent." Sovern, Race Disrimination and the National Labor Relations Act: The Brave New World of Miranda, N.Y.U. 16TH ANNUAL CONF. ON LABOR 3, 13-14 (1963).

In Comment, Refusal to Process a Grievance, the NLRB, and the Duty of Fair Representation: A Plea for Pre-emption, 26 U. PITT. L. REV. 593 (1965), four arguments are presented which allegedly support a finding of unfair representation as an unfair labor practice: (1) The courts have not satisfactorily discharged the government's obligation to the individual employee; (2) Because the NLRB is the "trustee" of the nation's labor policy, its effort to eliminate an existing evil should receive greater 
only conclusion properly drawn is that the legislative intent is unclear. A more convincing justification for the Board's inclusion of unfair representation within the section 8 (b) (l) (A) prohibitions accepts the premise that much deference is given the NLRB's implementation of any policy not in conflict with the provisions or purposes of the NLRA or other federal legislation. ${ }^{43}$

After positing that unfair representation is unfair labor practice under section 8 (b) (1) (A), the United Rubber Workers court appears to debilitate the doctrine of broad union discretion, including discrimination among members, in order to facilitate their representation. ${ }^{44}$ The Fifth Circuit's analysis implies that the scope of representational discretion will be viewed more restrictively in the administrative stage of the bargaining contract than in the negotiation stage. ${ }^{45}$ A decision not to process a grievance must be based upon criteria with a "'reasonable relation to the Union's role as bargaining representative or to its functioning as a labor organization." "48 To determine the constituents of a "reasonable relation," the court concludes, with apparent acceptance of the Steele rationale, ${ }^{47}$ that where evidence indicates that a grievance would have been processed to arbitration "but for arbitrary and discriminatory reasons," the refusal to process is a violation of the union's duty to provide its members with representation that is fair, impartial, and in " "good faith." "48 The necessary implication of the court's analysis is the rather forceful position that in every instance where racial discrimination is asserted, assuming arbitration is available and the movant's claim appears meritorious, the union must process the grievance to avoid a presumption of unfair representation. In light of the nature of the grievances which the United Rubber

consideration than that of a private litigant; (3) The NLRB can point to instances where the courts have made similar broad policy decisions when faced with much stronger arguments of contrary legislative intent; and (4) Since Congress gave no indication that the duty was not in the statute and since the Supreme Court found a duty, there is no need for an explicit mandate for a correlative right to be enforced by the NLRB. Id. at 605-06.

48 See NLRB v. Denver Bldg. \& Constr. Trades Council, 341 U.S. 675, 691.92 (1951) (NLRB's interpretation and application of the NLRA in doubtful situations is to be given weight).

"Compare note 12 supra, with notes 13 \& 14 supra.

¿s See $368 \mathrm{~F} .2 \mathrm{~d}$ at 17.

4368 F.2d at 19 (citing 150 N.L.R.B. 812, 317).

"See notes 15-20 supra and accompanying text.

48368 F.2d at 19. 
Workers court deemed unreasonable, however, it is probable that the court intended only to follow Steele and, in so doing, overstressed their conclusion without considering its implications.

The Fifth Circuit concluded that unfair representation did exist because of the union's failure to process grievances of the eight Negroes concerning backpay and segregated facilities. Following the Steele standard, the court ruled that the backpay grievance would have proceeded to arbitration "but for arbitrary and discriminatory reasons." 49 Much more difficult to rationalize, however, is the finding of unfair representation for failure to process the grievance concerning segregated facilities. The court deemed segregated facilities to be "conditions of employment" and implied that the union has an affirmative duty to bargain on discriminatory practices..$^{50}$ Rendering racially discriminatory employment procedures a mandatory bargaining subject is without significant precedent. Further, such a per se requirement appears ináppropriate since unions are usually allotted much greater discretion as to the most efficacious use of their bargaining power in negotiating contracts. ${ }^{51}$ Moreover, a primary difficulty is the absence of standards delineating the circumstances under which a union may represent the views of a majority of its members which endorse suppression of minority interests.

A more flexible position would allow that where a contract is nondiscriminatory and no extra-contractual arrangement to segregate exists, a union has no positive duty to demand desegregation but need only administer the contract fairly and bargain for adequate facilities for all its members. ${ }^{52}$ Otherwise, unions in effect become partially civil rights organizations fulfilling a governmental function more appropriately left to forums such as the Equal Employment Opportunity Commission. Arguably, requiring unions to insist upon desegregation would be detrimental to industrial tranquility, for advocacy of such a social view could weaken a union's position

10368 F.2d at 19.

${ }^{50}$ Id. at 19-20. Since the Goodyear segregated facilities were not dealt with in the collective bargaining contract, the holding that a meritorious grievance may arise from their existence implies that the union had an affirmative duty to bargain over them.

${ }^{81}$ See notes 12 \& 13 supra.

${ }^{2}$ See Cox, The Duty of Fair Representation, 2 VILt. L. REv. 151, 156 (1957) (the duty of fair representation does not impose upon unions "the affirmative obligation of making reasonable efforts to abolish racial discrimination"). See generally Sovern, The National Labor Relations Act and Racial Discrimination, 62 Colvm. L. REv. 563, 578-84 (1962). 
with the majority of its members and, ultimately, perhaps greatly impede unionism in the South.

Nevertheless, sanctioning unfair representation as an unfair labor practice more closely effectuates congressional and national policies than does the rejection of such a remedy. NLRB intervention offers certain advantages to both public and employee interests. The public benefits from the resulting industrial harmony. The employee realizes adjudicatorial advantages from the NLRB's broad powers of investigation, ${ }^{63}$ the NLRB's power to encourage informal settlements, ${ }^{54}$ the lack of litigation charges, ${ }^{55}$ and the possibility of earlier settlements which prevent lengthy terms of unemployment. ${ }^{50}$ Furthermore, the spotty history of recovery for court suits based upon unfair representation indicates that the employee has a greater chance of recovery before the NLRB. ${ }^{57}$

82 The NLRB's investigatory powers are detailed in \$11 of the NLRA, 29 U.S.C. $\$ 161$ (1964). See Blumrosen, supra note 9, at 1514-17; Comment, Refusal to Process a Grievance, the NLRB, and the Duty of Fair Representation: A Plea for Pre-emption, 26 U. PrTT. L. Rev. 593, 605-06, 618 (1965). But see Sovern, The National Labor Relations Act and Racial Discrimination, 62 CoLUM. L. Rev. 563, 611 (1962).

s4 See generally id.

${ }^{B 5}$ See 29 C.F.R. $\$ \$ 101.1-16$ (1966).

'os See Comment, Refusal to Process a Grievance, the NLRB, and the Duty of Fair Representation: A Plea for Pre-emption, 26 U. PITT. L. Rev. 593, 618 (1965).

${ }^{57}$ Professor Sovern reports that Negroes have gone to the courts to redress unfair representation on an average of less than once a year since Steele was decided. He attributes this dearth of litigation to the expense of counsel and adjudication. Sovern, Race Discrimination and the National Labor Relations Act: The Brave New World of Miranda, N.Y.U. 16TH ANNUAL CONF. ON LABOR 5-6 (1968).

From 1944 to 1964 Negro plaintiffs claimed approximately 6,000,000 dollars in compensatory and punitive damages, but collected only 2,802 dollars in compensatory and 3,000 dollars in punitive damages. Herring, The "Fair Representation" Doctrine: An Effective Weapon Against Union Racial Discrimination, 24 Mv. L. Rev, 113, 144 (1964). There are several reasons for the meager judicial enforcement. A heavy presumption of regularity in union affairs impedes a plaintiff's case. See Ford Motor Co. v. Huffman, 345 U.S. 330 (1953). Further, courts have erected procedural and technical barriers which adversely affect the employee-litigant. These include insistence upon pleading technicalities, application of doctrines which limit an em. ployee's right to sue a union, imposition of a requirement that contract remedies be exhausted, and hesitation in allowing arbitration to protect the employee. Blumrosen, supra note 9. One explanation for these reservations on the part of the courts is that they are unable to find standards by which to test the fairness of economic distinctions in collective agreements. See Wellington, Union Democracy and Fair Representation, 67 Y YLE L.J. 1327, 1357 (1958). Arguably then, less than adequate judicial enforcement would disappear as soon as standards were provided.

If the overall statistics of the NLRB in unfair labor practice cases were applied to unfair representation cases, approximately $66 \%$ of the cases would be withdrawn or dismissed before issuance of a complaint, about $25 \%$ would be settled or adjusted without need of a trial examiner's decision, and only $6 \%$ could go to the NLRB for a decision. 30 NLRB ANN. REP. 9-1I (1965). 
Perhaps the most persuasive practical argument against granting NLRB jurisdiction is that the public purpose of the NLRB in encouraging union-management cooperation may be achieved at the expense of the private interests of a majority of a local's members. ${ }^{58}$ The Fifth Circuit, however, maintains that the NLRB can best determine the proper balance between public and private interests. ${ }^{59}$ Moreover, since an unfair representation dispute would arise within a labor context, the NLRB is logically the best equipped agency to strike this necessary balance.

Noting that the claims of the union workers arose three years prior to the effective date of the Civil Rights Act of $1964,{ }^{80}$ the United Rubber Workers court implied that the Act's Equal Employment Opportunities Commission (EEOG) would not have had exclusive jurisdiction over such claims. ${ }^{61}$ There is no doubt that the Commission is a competent body to which a grievant with an unfair representation claim arising after the effective date might turn. Title VIII of the Act makes it an "unlawful employment practice" for a union to discriminate against "any individual because of his race, color, religion, sex, or national origin" or to cause or attempt to cause an employer to do so. ${ }^{62}$ Title VII's proscription clearly encompasses a potentially broad spectrum of action which might be classified as unfair representation. ${ }^{63}$

Because of the pervasiveness of this jurisdictional grant, a number of commentators contend that the EEOG should have exclusive competence over the various forms of unfair representation to which the Act applies. ${ }^{64}$ Congress inserted specific provisions in the Civil

${ }^{88}$ See Blumrosen, supra note 9, at 1516. Many in the labor field would dispute the assertion that the NLRB is more expert than the courts in handling unfair representation cases. See Sovern, The National Labor Relations Act and Racial Discrimination, 62 CoLUM. L. REv. 563, 611 (1962).

${ }^{80} 368$ F.2d at 23-24.

${ }^{\circ 0}$ The claims in United Rubber Workers arose more than three years prior to the effective date of Title VII of the Civil Rights Act-July 2, 1965. See §716(a)- (b), 42 U.S.C. $\$ 2000 \mathrm{e}(1964)$.

ex $\$ \$ 701-16$ (c), 42 U.S.C. $\$ \$ 2000 \mathrm{e}-15$ (1964).

${ }_{02}^{02} \S 703$ (c) (1), (3), 42 U.S.C. $\$ \S 2000 \mathrm{e}-2$ (c) (1), (3) (1964).

os Significant aspects of unfair representation remain without Title VII. See, e.g., Humphrey v. Moore, 375 U.S. 335 (1964) (seniority rights); NLRB v. Miranda Fuel Co., 326 F.2d 172 (2d Cir. 1963) (same); cf. Union News Co. v. Hildreth, 295 F.2d 658 (6th Cir. 1961) (dismissal of part of group because of thefts by the group as a whole).

or Professor Sherman concludes that the Civil Rights Act preempts the NLRA in overlapping areas. Sherman, supra note 23. Contra, Comment, 65 Colum. L. REv. 273, 282-85 (1965). 
Rights Act to force complainants to bring their suits for discrimination first under state law; only after these suits have failed may the plaintiffs resort to the EEOG. ${ }^{65}$ Since Congress failed to express explicitly a similar intention as to federal remedies, these commentators reason that federal labor remedies were impliedly superseded. ${ }^{68}$ However, it has also been argued that the NLRB should have concurrent jurisdiction on the ground that Congress merely intended to supplement all previously existing remedies with the Givil Rights Act. ${ }^{67}$

The above interpretations of the relationship between NLRB and EEOG jurisdiction, however, iguore the possibility that the respective competencies of the agencies are integrally related. Buttressing this view is the traditional presumption in statutory interpretations that, whenever possible, federal statutes should be construed so as to avoid a conflict. ${ }^{68}$ A construction which harmonizes the two jurisdictional grants can realistically posit the EEOC's broad focus on discrimination against private parties ${ }^{69}$ as a complement to the NLRB's specific duty of effectuating national labor goals even at the expense of articulated private interests. ${ }^{70}$

An unfair representation dispute pivoting on allegations of racial discrimination is an instance of intertwining public and private interests. Since various ramifications of national labor policy, including the extent of a union's discretion, would necessarily be raised by a claim of this nature, the NLRB is arguably a more appropriate forum than the non-adjudicatory EEOC to consider these broad implications. To the degree that the NLRA and prior NLRB de-

\footnotetext{
os $\$ \S 706$ (b), (c), 42 U.S.C. $\$ \S 2000 \mathrm{e}-5$ (b), (c) (1964). Subsection (c) provides that: "[T] Commission shall, before taking any action with respect to such charge, notify the appropriate State or local officials and, upon request, afford them a reasonable time ... to act under such State or local law to remedy the action alleged."

68 See Sherman, supra note 23, at 805.

or See, e.g., Comment, 65 ColuM. L. REv. 273, 282-85 (1965).

${ }^{88}$ See, e.g., United States v. Arizona, 295 U.S. 174 (1935); United States v. Jefferson Elec. Mfg. Co., 291 U.S. 386 (1934); Burnet v. Guggenheim, 288 U.S. 280 (1938); Musselman Hub-Brake Co. v. Commissioner, 199 F.2d 65 (6th Cir. 1943); Miller v. United States, 13 F. Supp. 684 (W.D.N.Y. 1986); Kleinfelter v. United States, 318 F.2d 929 (Ct. Cl. 1963); cf. Isbrandtsen Co. v. Johnson, 343 U.S. 779 (1952); United States v. Stewart, 311 U.S. 60 (1940).

"Compare note 19 supra, with Civil Rights Act of 1964, §703, 42 U.S.C. $\$ 2000$ e-2 (1964).

${ }^{70}$ See, e.g., Nathanson v. NLRB, 344 U.S. 25 (1952); Phelps Dodge Corp. v. NLRB, 313 U.S. 177 (1941); National Licorice Co. v. NLRB, 309 U.S. 350 (1940). See generally Note, 1966 DUEE L.J. 841.
} 
cisions do not provide guidelines by which to determine the precise components of unfair representation of a racially discriminatory nature, the Board could appropriately take special note of standards articulated by the EEOC and by the courts in adjudicating controversies involving the civil rights legislation. ${ }^{\text {11 }}$

Allowing direct interaction of the Civil Rights Act and the NLRA solves many of the problems confronting either exclusive or concurrent jurisdiction. The possibility of a double standard for adjudication raised by allowance of concurrent jurisdiction would be avoided since the NLRB would apply the Civil Rights Act determinants of discrimination in the context of national labor policy. ${ }^{72}$ Viewing the jurisdictions as complementary would also preserve the range of more effective NLRB enforcement mechanisms which would be forfeited if claims based on the Civil Rights Act could be asserted only in court proceedings. ${ }^{73}$

In addition to the interpretive problem outlined above, defining unfair representation as an unfair labor practice engenders other remedial questions. Arguably, recognition of discriminatory representation as a violation of section $8(\mathrm{~b})(\mathrm{l})(\mathrm{A})$ removes the jurisdic-

${ }^{71}$ For the NLRB to accept EEOC standards for ascertaining a racially-generated unfair representation would be a step seemingly comporting with the logical implication of a statement of the Supreme Court in the Steele decision: "We think that the Railway Labor Act imposes upon the statutory representative of a craft at least as exacting a duty to protect equally the interests of the members of the craft as the Constitution imposes upon a legislature to give equal protection to the interests of those for whom it legislates." 323 U.S. 192, 202 (1944). "Thus, if the Civil Rights Act of 1954 represents the legislative discharge of the above legislative duty, then Congressional intent articulated in the Act and judicial construction of its provisions are appropriate authority on which the NLRB could base standards to be applied in particular unfair representation controversies. See Cox, The Duty of Fair Representation, 2 VILL. L. REV. 151, 166 (1957); note 73 infra.

${ }^{2}$ It may appear that two bodies whose main orientations are so far apart would not develop similar standards. However, if the NLRB can concentrate on its primary function-collective bargaining-and at the same time take advantage of the EEOC's expertise in the civil rights field, then there is not a conflict in standards but a resulting "double expertise." Senator Humphrey stressed the importance of EEOC's maintaining an expertise in its specific a:cai in debate over the Civil Rights Bill. See 110 CoNG. REc. 14,188 (1964).

${ }^{73}$ Unlike the EEOC, the NLRB can issue cease and desist orders and can seek judicial enforcement of its orders. NLRA $\$ 10$ (c), (e), 29 U.S.C. $\$ 160$ (c), (c) (1964). The EEOC is not entitled to initiate a civil action on behalf of an aggrieved party, but can only seek to remedy the discrimination through informal methods of conciliation. $\$ \S 706$ (a), (e), (f), 42 U.S.C. $\$ \S 2000 ;-5$ (a), (c), (f) (1964). The entire NLRB procedure would probably provc more favorable to aggrieved parties since the NLRB can investigate complaints, conduct hearings, issue findings, and seek enforcement. See NLRA § 10, 29 U.S.C. §160 (1964). See generally Sherman, Union's Duty of Fair Representation and the Civil Rights Act of 1964, 49 MiNN. L. REv. 771, 805 (1965). 
diction of the courts to directly enforce fair representation, a power which has existed since Steele and Wallace under the somewhat tenuous theory that an absence of administrative remedies left the courts as the sole adjudicatory body. ${ }^{74}$ Yet, it is possible that Ford Motor Company v. Huffman, ${ }^{75}$ and other cases involving claims of unfair representation decided subsequent to enactment of the unfair labor practices, could be construed as holding that the courts retain jurisdiction whether or not unfair representation is an unfair labor practice. However, the Supreme Court held, ${ }^{76}$ subsequent to the above cases, that in situations in which an unfair labor practice may be involved, the courts must defer to the jurisdiction of the NLRB. ${ }^{77}$ Nevertheless, the Court has recently indicated that fair representation is an exception to the doctrine of preemption with resulting concurrent jurisdiction in the courts and NLRB. ${ }^{78}$

On the other hand, since Congress has explicitly preserved judicial power under section $301(\mathrm{a}),{ }^{79}$ an overlap between NLRB

74 See notes 20-22 supra and accompanying text.

75345 U.S. 330 (1953).

7o San Diego Bldg. Trades Council v. Garmon, 359 U.S. 236 (1959).

${ }_{77}$ "When an activity is arguably subject to $\$ 7$ or $\$ 8$ of the Act, the States as well as the federal courts must defer to the exclusive competence of the National Labor Relations Board if the danger of state interference with national policy is to be averted." Id. at 245 . This principle of exclusive NLRB jurisdiction is based upon two factors: (1) In 1947, when Congress added restraints on unions to the existing restraints on employers, it adopted a comprehensive code of substantive law relating to labor relations that forecloses the application of any potentially conflicting substantive law. See id. at 243-45; Garner v. Teamsters Union, 346 U.S. 485, $499-500$ (1953); Blumrosen, The Worker and Three Phases of Unionism: Administrative and Judicial Control of the Worker.Union Relationship, 61 MIch. L. Rxv. 1435, 1517.18 (1963). (2) Congress evidenced a preference for federal administrative enforcement of the code, to the exclusion of other methods of enforcement, by purposely placing administrative responsibility in the NLRB. See San Diego Bldg. Trades Council v. Garmon, 359 U.S. 236, 242 (1959): ". . . Congress has entrusted administration of the labor policy for the Nation to a centralized administrative agency, armed with its own procedures, and equipped with its specialized knowledge and cumulative experience... ." The Court further stated that: "When the exercise of state power over a particular area of activity threatened interference with the clearly indicated policy of industrial relations, it has been judicially necessary to preclude the States from acting . ..." Id. at 243. "When it is clear or may fairly be assumed that the activities which a State purports to regulate are protected by $\$ 7$ of the National Labor Relations Act, or constitute an unfair labor practice under $\$ 8$, due regard for the federal enactment requires that state jurisdiction must yield." Id. at 244. See Garner v. Teamsters, supra at 490: "Congress evidently considered that centralized administraiton of specially desigued procedures was necessary to obtain uniform application of its substantive rules and to avoid these diversities and conflicts likely to result from a variety of local procedures and attitudes toward labor controversies."

${ }^{78}$ Vaca v. Sipes, 386 U.S. 171, 176-88 (1967).

70 NLRA $\$ 301$ (a), 29 U.S.C. $\$ 185$ (1964). Section 301 (a) provides: "Suits for viola. 
and judicial jurisdiction may still exist. Further, interpretation of that section has affirmed that courts can entertain the claim of an aggrieved employee which is based essentially on a breach of contract, even though it might also involve an unfair labor practice. ${ }^{80}$ Thus the Fifth Circuit concluded that there would be concurrent jurisdiction if a claim of unfair representation involved a breach of contract. ${ }^{81}$ In cases where the unfair representation involves no breach of the bargaining contract, assuming unfair representation is not construed as a prima facie breach, ${ }^{82}$ the NLRB would have exclusive jurisdiction if no other federal statute were involved. ${ }^{83}$

tion of contracts between an employer and a labor organization representing employees ... may be brought in any district court of the United States having jurisdiction of the parties . . . " Judicial power is also reserved by Congress under LMRA § 101 (4), 29 U.S.C. $\$ \S 151-67$ (1964) ("No labor organization shall limit the right of any member thereof to institute an action in any court ....") and NLRA \$ 303 (b), 29 U.S.C. \$187 (1964) (awarding of damages for illegal secondary boycott). In addition, the courts have preserved state injunctive power where labor disputes lead to violence. Further, the states may compensate for the consequences of conduct marked by imminent threats to public order. International Union, UAW v. Russell, 356 U.S. 634 (1958); see United Constr. Workers v. Laburnum Constr. Corp., 347 U.S. 656 (1954). Injunctions have also been allowed against such conduct. Youngdahl v. Rainfair, Inc., 355 U.S. 131 (1957); UAW v. Wisconsin Employment Relations Bd., 35I U.S. 266 (1956). "State Jurisdiction has prevailed in these situations because the compelling state interest, in the scheme of our federalism, in the maintenance of domestic peace is not overridden in the absence of clearly expressed Congressional direction." San Diego Bldg. Trades Council v. Garmon, 359 U.S. 236, 247 (1959).

${ }^{80}$ See Humphrey v. Moore, 375 U.S. 335 (1964); Smith v. Evening News Ass'n, 371 U.S. 195 (1962).

${ }^{82}$ The United Rubber Workers court interpreted the previous cases to hold that where a violation is of a "hybrid" nature-breach of contract and an unfair labor practice-the employee is free to invoke the primary jurisdiction of the NLRB or to proceed in the courts. 368 F.2d at 22. See Smith v. Evening News Ass'n, 371 U.S. 195, 197 (1962): "The authority of the Board to deal with an unfair labor practice which also violates a collective bargaining contract is not displaced by $\S 301$, but it is not exclusive and does not destroy the jurisdiction of the court in suits under $\$ 301 . "$

${ }^{82}$ Compare Humphrey v. Moore, 375 U.S. 335 (1964), with id. at 351 (Goldberg, J., concurring). See generally Comment, Refusal to Process a Grievance, the NLRB, and the Duty of Fair Representation: A Plea for Pre-emption, 26 U. PItr. L. REv. 593 (1965).

${ }^{83}$ See San Diego Bldg. Trades Council v. Garmon, 359 U.S. 236 (1959). The United Rubber Workers court felt exclusive NLRB jurisdiction was desirable, since the aggrieved employee would no longer have to shop for a proper forum. 368 F.2d at 22-23. Previously, the plaintiff first had to go to the NLRB if his claim was based essentially on an unfair labor practice, though couched in terms of breach of contract, but had to begin anew in the courts if the NLRB concluded that the only violation involved in his claim was a breach of the duty of fair representation. Local 100, United Ass'n of Journeymen v. Borden, 373 U.S. 690, 698 (1963): "In the present case the conduct on which the suit is centered, whether described in terms of tort or contract, is conduct whose lawfulness could initially be judged only by the federal agency vested with exclusive primary jurisdiction to apply federal standards."; accord, Local 207, Bridge Workers v. Perko, 373 U.S. 701 (1963). However, the plaintiff would 
However, the Fifth Circuit provides no guide to distinguish situations in which the NLRB is simply construing a collective bargaining contract to ascertain if there is an unfair labor practice ${ }^{84}$ from those in which the interpretation will involve determination of the contractual rights of individual employees. ${ }^{85}$

Although the NLRB's conclusion that a section 8(b)(l)(A) violation existed in United Rubber Workers presents an appealing mode for policing unfair representation, such a remedy may not be the most appropriate one currently available. However, if the jurisdictional and policy problems can be satisfactorily resolved judicially, section 8 (b) (I) (A) may become the most efficient alternative. ${ }^{86}$ In the absence of adjudicatorial resolution of these problems to the preservation of minority interests, Congress should re-enter this statutory area, denominate section $8(\mathrm{~b})(\mathrm{l})(\mathrm{A})$ as the appropriate remedy, and provide broad policy guidelines for NLRB jurisdiction.

not necessarily have to begin with the NLRB if he brought his suit under $\$ 301$. See Humphrey v. Moore, 375 U.S. 335 (1964) . Of course, these jurisdictional problems would not exist if the NLRB is deemed to have jurisdiction over unfair representation under $\$ 8(\mathrm{~b})$ (1) (A), for the NLRB would not be forced to defer to judicial jurisdiction. 84 See NLRB v. C \& C Plywood, 385-U.S. 421 (1967).

${ }^{85}$ See generally Sovern, Section 301 ard the Primary Jurisdiction of the NLRB, 76 HARV. L. REV. 529 (1963).

so Since the fifth circuit covers most of the southern states, unfair representation as an unfair labor practice could prove highly useful in supplying an easy and expedi. ent method of protecting Negroes from unfair representation and yet not arouse regional hostility since the protection is not the product of a "civil rights" organization such as the EEOC. 